\title{
Creation of new initial forms of black currant (Ribes nigrum L.) in breeding for adaptation
}

\author{
Fedor Sazonov ${ }^{1, *}$, Ivan Kulikov ${ }^{1}$, Tatyana Tumaeva ${ }^{1}$, and Irina Sazonova ${ }^{2}$ \\ ${ }^{1}$ FSBSI "Federal Breeding and Technological Center of Horticulture and Nursery", 115598 Moscow, \\ Russian Federation \\ ${ }^{2}$ FSBEI HE Bryansk State Agrarian University, 243365 Kokino village, Vygonichsky district, \\ Bryansk region, Russian Federation
}

\begin{abstract}
The article presents the results of studying the black currant varieties collection of the Kokinsky control station of the FSBSI FRC for Horticulture (Bryansk region) for winter hardiness, resistance to Sphaerotheca, and currant gall mite in order to create new initial forms based on the selected genotypes, characterized by a high level of adaptation for their inclusion in the breeding work to improve the crop assortment. The best combinations of crosses (Gamayun $\times$ Nara, 33-27-1 $\times$ Kipiana, 33-27-1 $\times$ Bryanskiy Agat, Favorit $\times$ Dar Smolyaninovoy, etc.), the initial forms for inbreeding and free pollination, in the progeny of which the largest number of winter-hardy seedlings, characterized by resistance to Sphaerotheca and gall mite, were identified. Promising winter-hardy Sphaerotheca-resistant forms were identified 4-63-4, 72-03-7, 3-37-26/02, 62-03-7, 1-5-1, 63-35-1, 3-134-01, 28-03-1, 5-82-02, 1-91-01, immune to gall mite.
\end{abstract}

\section{Introduction}

One of the most popular and affordable berry crops is black currant (Ribes nigrum L.), the therapeutic and nutritional value of which is well known to everyone. The increased interest in this crop is explained by the fact that its fruits are rich in biologically active agents, trace elements, essential oils and play an important role in human nutrition. Many of these agents (vitamin $\mathrm{C}, \beta$-carotene, bioflavonoids cyanidin-3-glucoside, delphinidin-3rutinoside, etc.) are natural antioxidants that help to increase the resistance of the human body to stress factors [1]. Almost all organs of black currant have nutritional and medicinal value. Leaves and berries are the most accessible source of ascorbic acid and P-active agents, combined effect of which has a therapeutic effect in the treatment of many diseases. Based on the wet weight, black currant berries contain an average of 160-240 mg/100 $\mathrm{g}$ of ascorbic acid, up to $1500 \mathrm{mg} / 100 \mathrm{~g}$ of phenolic compounds (anthocyanins, catechins, leucoanthocyanins and other biologically active substances) [2, 3]. Moreover, in terms of anthocyanin content, its fruits are one of the leaders among fruit and berry crops (up to180 $\mathrm{mg} / 100 \mathrm{~g}$ of the edible part), and the use of $100 \mathrm{~g}$ of berries provides up to $88 \%$ of the daily requirement of dietary fibre, on average they contain about $4.3 \%$ [4]. It is important that the

${ }^{*}$ Corresponding author: sazon-f@yandex.ru 
pectin agents of currant fruits are able to bind heavy metal ions, radionuclides and remove them from the human body, and therefore, black currant is classified as an anti-radiant plant [5].

The leaders in the production of currant berries are Russia, Poland, Germany, Ukraine, Great Britain, Austria, France, and the Czech Republic [6]. In the United States and Canada, black currant has not received such popularity as in Western Europe and Russia [7]. According to FAOSTAT [8], the volume of world production of currant berries is constantly increasing and in 2019 amounted to 647815 tons on an area of 141115 hectares. Statistics show that since 1985, the area under the crop in the world is approximately at the same level, but the gross production increases due to the improvement of technologies and assortment renewal. In the Russian Federation in 2019, 417,600 tons of berries were produced on an area of 72,318 hectares, with an average yield of $5.77 \mathrm{t} / \mathrm{ha}$, while in Poland, 126,190 tons of berries were harvested from an area of 43,350 hectares.

Modern black currant varieties have quite high requirements, which is due to the large number of already created varieties included in the State Register. As of 2020, their number already reaches 205 varieties [9]. In this connection, new varieties should combine resistance to extreme environmental factors, pests and diseases (gall mite, powdery mildew), have cultivation processability, including suitability for machine harvesting, high yield (not less than $12 \mathrm{t} / \mathrm{ha}$ ) and fruit quality [10, 11, 12]. To create such varieties in breeding, genetic sources of the listed traits and properties are needed in order to conduct purposeful breeding work. The purpose of our research was to study the black currant genetic collection of the Kokinsky CS of the FSBSI FRC for Horticulture for resistance to winter damaging factors, Sphaerotheca, currant gall mite and to create new initial forms on the basis of the isolated genotypes, characterized by a high level of adaptation for their inclusion in the breeding work to improve crop assortment.

\section{Materials and methods}

The research was conducted on the basis of the Kokinsky control station of the FSBSI FRC for Horticulture (Bryansk region) from 2005 to 2020. The object of research is the genetic collection of black currant, represented by varieties of such scientific institutions as FSBSI VNIISPK, FSBSI "FRC n.a. I.V. Michurin", FSBSI FRC "VIK n.a. V.R. Williams", FSBSI "Federal Altai Scientific Center of Agrobiotechnologies", FSBSI "Ural Federal Agrarian Research Center of the Ural Branch of the Russian Academy of Sciences", FSBSI "FIC Russian Institute of Plant Genetic Resources n.a. N.I. Vavilov", as well as Ukrainian, Belarusian, Polish, Scottish and Swedish breeding. The progeny of 37 crosses combinations, 5 populations from free pollination and 5 from self-pollination in the amount of 2853 pieces were studied. The initial forms are represented in different combinations by derivatives of the species $R$. n. subsp. europaeum Jancz., $R$. n. sibiricum, $R$. scandinavicum, $R$. dikuscha, $R$. ussuriense, $R$. glutinosum, $R$. sanguineum, $R$. petiolare, etc. The study of the varieties collection, the hybrid fund and the breeding work were carried out according to the relevant methods $[13,14]$.

Accounting for branches and buds freezing in the field was carried out in the spring after leaf flushing, when the damage is clearly visible, on a 5-point scale: 0 - no signs of freezing; 1 - no more than a quarter of the length of annual growth is frozen, $10 \%$ of the buds are frozen, the harvest is expected to be normal; 2 - complete freezing of individual shoots and individual branches of older age is possible, up to $25 \%$ of the buds are frozen; 3 - there is freezing of two-year wood of individual perennial branches and up to $50 \%$ of the buds, zero shoots can grow back; 4 - most of the perennial branches of the shrub are frozen, up to $75 \%$ of the buds; 5 - the plant is frozen and died. 
The degree of damage by American mildew was evaluated on a 5-point scale: 0 - no damage; 1 - very weak: single leaves are affected, up to $1 \%$ of berries; 2 - weak: affected up to $1 / 4$ of the shoot length, up to $25 \%$ of leaves, $1-3 \%$ of berries; 3 - medium: affected from $1 / 4$ to $1 / 3$ of the shoot length, $26-50 \%$ of leaves, $4-10 \%$ of berries; 4 - strong: affected from $1 / 3$ to $1 / 2$ of the shoot length, $51-70 \%$ of leaves, $11-20 \%$ of berries; 5 - very strong: affected more than $1 / 2$ of shoot length, $>70 \%$ of leaves, $>20 \%$ of berries.

The degree of damage to the currant gall mite was assessed in points in the spring before budding: 0 points - no signs of damage; 1 point - very weak damage to individual buds; 2 points - weak damage: up to $10 \%$ of buds are infected with the gall mite; 3 points medium: up to $30 \%$ of buds are damaged; 4 points - strong: from 30 to $50 \%$ of buds are damaged; 5 points - very strong: $>50 \%$ of buds are damaged.

Agrotechnics in the black currant cultivation is generally accepted in the NonChernozem zone of Russia. The precursor is seed green-manured fallow, green-manure crops of white mustard and legume-grass mixture. The planting scheme is single-row, the distance between the rows is $3 \mathrm{~m}$, between the plants $-0.8 \mathrm{~m}$. The arable horizon thickness is $25 \mathrm{~cm}$. The soils of the breeding area are gray forest medium loamy slightly acidic $(\mathrm{pH}$ 6.1) with a humus content of 2.6-3.2\%, 25-35 mg of $\mathrm{P}_{2} \mathrm{O}_{5}$ per $100 \mathrm{~g}$ of soil, 9.8-14.1 $\mathrm{mg}$ of $\mathrm{K}_{2} \mathrm{O}$ per $100 \mathrm{~g}$ of soil.

\section{Research results}

It is known that the winter hardiness of currant depends not only on the characteristics of the variety, but also largely on the cultivation conditions $[15,16,17]$. In the conditions of the Bryansk region, the crop is quite hardy and able to withstand quite low temperatures. In the conditions of the south-west of the Non-Chernozem region of Russia, severe winters occur quite often, temperatures can drop to $-24 \ldots-32{ }^{\circ} \mathrm{C}$. Under these conditions, of the 140 varieties studied for the period from 2005 to 2020 , only $20 \%$ had freezing of vegetative organs of 3.5-4.0 points. Nevertheless, prolonged winter thaws, with an increase in temperature above $0{ }^{\circ} \mathrm{C}$, provoke the loss of plant hardening, and subsequent frosts damage the vegetative-generative organs [11].

To create winter-hardy forms, it was necessary to select genotypes for further crosses; for this purpose, the state of plants in black currant genetic collection after extreme winters with provocative thaws was analyzed. Similar conditions were observed in the winter of 2006/2007, when, under the influence of a three-week December-January thaw (up to +6 ${ }^{\circ} \mathrm{C}$ ), the buds began to swell, burst and start to grow. Under these conditions, some cultivars showed the extension of the bud scales (Sharovidnaya, Sudarushka, Chereshneva, Effect, Nara, Rita, Selechenskaya 2), the beginning of budding and partial leaves extension (Chelyabinsk, Podarok Kuminovu, Glariosa, Yadrenaya, Bagira, Gratsiya, Tserera, etc.). The noted varieties subsequently suffered more from the February frosts (up to $-20.1{ }^{\circ} \mathrm{C}$ ), remaining without crop in the future.

The premature exit of plants from the dormant period, along with the beginning of growth processes, led to increased transpiration, and subsequent frosts contributed to shoots drying (frost destruction). In the winter of 2006/07, strong frost destruction of branches was observed in the varieties Lama, Slatyona, Tserera, Delikates, Effect, Veloy, Amethyst, Zelenaya dymka, which led to crop loss. At the same time, genotypes were identified that were not affected by such changes. Ергы, the varieties Barmaley, Perun, Golubichka, Elevesta, Debryansk, Lama, Triton, Legenda, Pamyat Vavilova, Amethyst, Rtishchevskaya, Sanyuta, Selechenskaya, Petersburzhenka, Sevchanka, Sozvezdiye, Poesia, Strelets, Orlovsky Vals, Trilena, Mriya, Delikates, Charodey, Gulliver, 10-41-2 (Venera $\times$ Nara), 45-2 (SK-7 $\times$ Exotica), 7-79-4 (Exotica $\times$ Gamayun) were without signs of growth process beginning. The winter-hardy genotypes isolated during research were used by us in the 
hybridization of subsequent years, which allowed later to select forms that can withstand such temperature changes in winter.

Also, in the Bryansk region, the winter of 2019/2020 stands out for its extreme nature. In the first decade of December, the average air temperature was $+3{ }^{\circ} \mathrm{C}$, on some days it rose to $+9{ }^{\circ} \mathrm{C}$, with almost no snow cover. In January 2020, the average daily air temperature was $0{ }^{\circ} \mathrm{C}$ with an increase in daytime hours to $+3{ }^{\circ} \mathrm{C} . . .+5{ }^{\circ} \mathrm{C}$. Daytime positive temperatures were replaced by small night frosts up to $-5{ }^{\circ} \mathrm{C}$. Subsequent frosts contributed to shoots drying. Especially strongly frost destruction ща shoots with a delay in development in the first phases of the growing season was noted in the varieties Zelenaya dymka, Delikates, Veloy, Amethyst, which subsequently led to a partial loss of yield.

It was found that in the conditions of the Bryansk region, even after unfavorable winters, the varieties of breeding of the FSBSI FRC for Horticulture Charodey, Gamayun, Kudesnik, Podarok veteranam, Debryansk froze by no more than 0.5 points (the ends of single annual shoots froze), which did not affect their subsequent productivity. Under the same conditions, the varieties Strelets, Bryanskiy Agat, Barmaley, Favorit, Kaskad, Mif and elites 4-63-4 (Strelets $\times$ Golubichka), 33-27-1 (Strelets $\times$ Selechenskaya 2), 1-91-01 (Sanyuta $\mathrm{I}_{1}$ ), 39-3-3/05 (Monisto free pollination), 63-35-1 (Lentyay $\times$ Debryansk), 5-43/02 (Dar Smolyaninovoy $\times$ Litvinovskaya), 36-27-4/05 (Debryansk fr. pol.), 5-30-95 (Orlovskaya Serenada $\mathrm{I}_{1}$ ), 62-03-7 (Venera $\times$ Barmaley) showed no signs of freezing even in winters with provocative thaws. All the selected varieties and selections deserve active use in further breeding work to increase the winter hardiness of future varieties.

In the conditions of the Bryansk region, the first signs of American mildew (Sphaerotheca mors-uvae (Schw) Berk et Gurt.) appear in late May on growing shoots and leafstalks in the form of a white plaque, and in mid-late June it becomes widespread, spreading to young leaves and ovaries [11]. To date, some varieties that were previously considered resistant to the disease and are actively involved in the breeding process are affected by Sphaerotheca to a different extent. This is due to the ability of the pathogen to mutational variability, as a result, new biotypes can infect previously resistant varieties [18, 19]. This is often observed among potential $R$ gene donors derived from the Sunderbyn-II variety [20]. Similarly, the Brödtorp variety [5, 21], which was previously actively involved in breeding work for resistance to Sphaerotheca, is affected by up to 2.5 points in the Bryansk region [22].

The assessment of the genetic collection of the Kokinsky CS of the FSBSI FRC for Horticulture allowed to identify several varieties that are resistant to Sphaerotheca pathogen even during periods of intensive epiphytoties development. These are such varieties as Vertical, Chudnoye mgnoveniye, Gamayun, Titania, Gratsiya, Slastyona, Dar Smolyaninovoy, Sofiyivskaya, Orlovskaya serenada, Delikates, Sanyuta, Litvinovskaya, Nara, Shans, Tamerlan, Orloviya, Orlovsky Vals, Kipiana, Pamyat Vavilova, Shalunya, Selechenskaya 2, Rita, Katyusha, Sevchanka, Zusha, Gulliver, Dachnitsa, Trilena, Gamma, Chereshneva, Bagira, Sharovidnaya. Some of them were actively involved in further breeding work in order to obtain Sphaerotheca-resistant progeny in different crosses variations: resistant with resistant, resistant with medium-resistant forms, etc.; seedlings from self- and free pollination of genotypes of different pathogen resistance were also studied (Table 1).

Table 1. Yield of Sphaerotheca-resistant black currant seedlings depending on the parental forms

\begin{tabular}{|c|c|c|c|c|}
\hline $\begin{array}{c}\text { Crossbreeding combinations, } \\
\text { populations from inbreeding } \\
\text { and free pollination }\end{array}$ & \multirow{2}{*}{$\begin{array}{c}\text { Seedlings } \\
\text { studied, pcs. }\end{array}$} & \multicolumn{2}{|c|}{$\begin{array}{c}\text { Isolated resistant to } \\
\text { powdery mildew }\end{array}$} & $\begin{array}{c}\text { Average } \\
\text { affection } \\
\text { score } \mathrm{F}_{1}\end{array}$ \\
\cline { 3 - 4 } & \multicolumn{2}{|c|}{ pcs. } & $\%$ & \\
\hline Resistant $\times$ resistant \\
\hline Gamayun $\times$ Nara & 64 & 60 & 93.8 & 0.1 \\
\hline Exotica $\times$ Gamayun & 63 & 40 & 63.5 & 0.4 \\
\hline
\end{tabular}




\begin{tabular}{|c|c|c|c|c|}
\hline Gamayun $\times$ Gulliver & 65 & 39 & 60.0 & 0.5 \\
\hline Nara $\times$ Selechenskaya 2 & 59 & 31 & 52.5 & 0.5 \\
\hline Orloviya $\times$ Nara & 75 & 35 & 46.7 & 0.6 \\
\hline Nara $\times$ Delikates & 74 & 34 & 45.9 & 0.6 \\
\hline $\begin{array}{c}(762-5-82 \times \text { Dobrynya }) \times \\
\text { Selechenskaya } 2\end{array}$ & 57 & 24 & 42.1 & 0.6 \\
\hline \multicolumn{5}{|c|}{ Resistant $\times$ non-resistant } \\
\hline Litvinovskaya $\times$ Tiben & 60 & 22 & 36.7 & 0.7 \\
\hline $\begin{array}{c}\text { Nara } \times 8-4-1 \text { (Yadrenaya } \times \\
\text { Exotica) }\end{array}$ & 52 & 14 & 30.0 & 0.9 \\
\hline \multicolumn{5}{|c|}{ Non-resistant $\times$ resistant } \\
\hline Tiben $\times$ Litvinovskaya & 54 & 20 & 37.0 & 0.7 \\
\hline Strelets $\times$ Selechenskaya 2 & 73 & 17 & 23.3 & 1.1 \\
\hline Yadrenaya $\times$ Orloviya & 52 & 0 & 0 & 1.4 \\
\hline \multicolumn{5}{|c|}{ Non-resistant $\times$ non-resistant } \\
\hline Strelets $\times$ Golubichka & 53 & 3 & 5.7 & 1.2 \\
\hline Dobrynya $\times$ Venera & 77 & 3 & 2.6 & 1.2 \\
\hline \multicolumn{5}{|c|}{ Seedlings from self-pollination } \\
\hline Ben Tirran $\mathrm{I}_{1}$ & 72 & 12 & 16.7 & 0.8 \\
\hline Orlovskaya Serenada $\mathrm{I}_{1}$ & 63 & 10 & 15.9 & 0.9 \\
\hline Sanyuta $I_{1}$ & 67 & 9 & 13.4 & 1.1 \\
\hline Lukomorye $\mathrm{I}_{1}$ & 55 & 7 & 12.7 & 1.2 \\
\hline Rita $I_{1}$ & 78 & 0 & 0 & 1.3 \\
\hline \multicolumn{5}{|c|}{ Seedlings from free pollination } \\
\hline Kipiana & 120 & 17 & 14.2 & 0.9 \\
\hline Litvinovskaya & 112 & 12 & 10.7 & 1.1 \\
\hline Mriya-5 & 105 & 3 & 2.9 & 1.1 \\
\hline Tiben & 123 & 4 & 3.3 & 1.1 \\
\hline Mriya & 70 & 2 & 2.9 & 1.2 \\
\hline
\end{tabular}

The weather conditions of the spring-summer period of 2011 contributed to the intensive development and spread of the Sphaerotheca in the black currant plantings. It was a moderately humid and warm season, often with air and soil waterlogging, the hydrothermal coefficient was 1.53 , which indicates excessive moisture, with a total of active temperatures of $727.7^{0} \mathrm{C}$. All this contributed to the mass spread of the phytopathogen. The prevailing weather conditions made it possible to more objectively evaluate seedlings and select pathogen-resistant plants. Hybridological analysis showed that the highest yield of Sphaerotheca-resistant progeny was observed if all parental genotypes were resistant to the pathogen. These are such crossbreeding combinations as Exotica $\times$ Gamayun, where $63.5 \%$ of resistant hybrids were isolated, Gamayun $\times$ Gulliver $(60.0 \%)$, Nara $\times$ Selechenskaya $2(52.5 \%)$, Orloviya $\times$ Nara $(46.7 \%)$, Nara $\times$ Delikates $(45.9 \%)$. Up to $93.8 \%$ of resistant seedlings were isolated in the Gamayun $\times$ Nara family, and the degree of damage to hybrids in the average population was 0.1 points.

Gamayun and Nara varieties are able to transmit high resistance to disease pathogen to their progeny. With their participation, a number of selected forms were obtained, which, even with a strong spread of epiphytoty, showed high resistance to disease pathogen along with high productivity. Case in point is selections No. 7-79-4 (Exotica $\times$ Gamayun), 10-161/02 (Nara $\times$ Delikates), 1-5-1 (Gamayun $\times$ Nara), 28-03-1 (Gamayun $\times$ Gulliver), 72-03-7 (Orloviya $\times$ Nara), 21-22-3/05 (Nara $\times$ Selechenskaya 2). The large-fruited variety Favorit (Orloviya $\times$ Nara) and the early-maturing dessert variety Bryansky Agat (Gamayun $\times$ Nara) created in the FSBSI FRC for Horticulture are distinguished by their Sphaerothecaresistance and reliable winter hardiness. 
The crossing of Sphaerotheca-resistant varieties with unstable parental forms also allowed to identify a significant proportion of tolerant progeny: Litvinovskaya $\times$ Tiben $6.7 \%$, Nara $\times 8-4-1-30.0 \%$, Tiben $\times$ Litvinovskaya $-37.0 \%$, Strelets $\times$ Selechenskaya $2-$ 23.3\%. Among their progeny, promising stable forms were identified: 8-69-01 $($ Litvinovskaya $\times$ Tiben), 5-82-02 (Tiben $\times$ Litvinovskaya), 33-27-1 (Strelets $\times$ Selechenskaya 2). In some populations, where the male and female forms are unstable to the pathogen genotypes, there is a possibility of tolerant progeny selection. Thus, in the families of Dobrynya $\times$ Venera and Strelets $\times$ Golubichka from 2.6 to $5.7 \%$ of hybrids resistant to the phytopathogen were isolated. In their progeny, the Sphaerotheca-resistant large-fruited selections 4-63-4 (Strelets $\times$ Golubichka) and 3-37-26/02 (Dobrynya $\times$ Venera) were isolated. The fact that tolerant genotypes were identified in the progeny of the original forms resistant to the disease indicates the possibility of creating hybrids resistant to powdery mildew.

The study of populations from self-pollination allowed to identify a small number of resistant seedlings, which is explained by the inbred depression of such progeny. The most promising was the inbred of the varieties Sanyuta $I_{1}$, Orlovskaya Serenada $I_{1}$ and Ben Tirran $\mathrm{I}_{1}$, where from 13.4 to $16.7 \%$ of seedlings resistant to powdery mildew were isolated, respectively. Moreover, in the last two populations, the average lesion was less than 1 point, which indicates the prospects of using the varieties Orlovskaya Serenada and Ben Tirran in further breeding work for resistance to Sphaerotheca. The selected inbreds (1 91-01 (Sanyuta $\mathrm{I}_{1}$ ), 3-112-01 (Ben Tirran $\mathrm{I}_{1}$ ), 5-30-95 (Orlovskaya Serenada $\mathrm{I}_{1}$ ), etc.) are involved in further self-pollination to obtain homozygous lines. In the populations obtained by sowing the seed from free pollination, a small proportion of stable progeny was noted. However, the sowing of seeds of the Litvinovskaya and Kipiana varieties tolerant to Sphaerotheca allowed to select from 10.7 to $14.2 \%$ of resistant seedlings, respectively. The selected form 3-134-01 (Kipiana free pollination), along with resistance to Sphaerotheca, is also immune to gall mite, and the selection 8-15-02 (Litvinovskaya free pollination) is characterized by the dessert taste of the fruit.

The inclusion of the resistant forms obtained in crosses with resistant varieties allowed to obtain populations where more than $50 \%$ of pathogen resistant seedlings were isolated (Table 2). The only exceptions are the combinations of crosses 18-18-6/05 $\times$ Selechenskaya 2 and Dachnitsa $\times$ Bryanskwy Agat. The use of the promising form 33-27-1 as one of the parents in crosses with the varieties Kipiana and Bryanskiy Agat allowed to obtain progeny not affected by powdery mildew during the entire observation period. In the combinations of crosses Tamerlan $\times$ Favorit and 1-5-1 $\times$ Kipiana, 93.3 and $97.0 \%$ of stable seedlings were isolated, respectively, both in the second and fourth years of observations.

Table 2. Dynamics of black currant hybrid progeny infestation with powdery mildew

\begin{tabular}{|c|c|c|c|c|c|c|c|c|c|c|c|c|c|}
\hline \multirow{3}{*}{ Hybrid combinations } & \multirow{3}{*}{$\begin{array}{c}\text { Hybrids } \\
\text { studied, } \\
\text { pcs. }\end{array}$} & \multicolumn{6}{|c|}{ 2-year-old hybrids } & \multicolumn{6}{|c|}{ 4-year-old hybrids } \\
\hline & & \multicolumn{12}{|c|}{$\%$ of affected plants, score } \\
\hline & & 0 & 1 & 2 & 3 & 4 & 5 & 0 & 1 & 2 & 3 & 4 & 5 \\
\hline 33-27-1 × Kipiana & 28 & 100 & 0 & 0 & 0 & 0 & 0 & 100 & 0 & 0 & 0 & 0 & 0 \\
\hline Kipiana $\times 33-27-1$ & 37 & 100 & 0 & 0 & 0 & 0 & 0 & 100 & 0 & 0 & 0 & 0 & 0 \\
\hline 33-27-1 $\times$ Bryanskiy Agat & 43 & 100 & 0 & 0 & 0 & 0 & 0 & 100 & 0 & 0 & 0 & 0 & 0 \\
\hline $\begin{array}{l}\text { Bryanskiy Agat } \times \\
\text { Litvinovskaya }\end{array}$ & 27 & 74.1 & 22.2 & 3.7 & 0 & 0 & 0 & 66.7 & 25.9 & 7.4 & 0 & 0 & 0 \\
\hline Bryanskiy Agat $\times$ Gulliver & 58 & 81.0 & 8.6 & 5.2 & 3.5 & 1.7 & 0 & 72.4 & 20.7 & 6.9 & 0 & 0 & 0 \\
\hline Tamerlan $\times$ Favorit & 30 & 93.3 & 6.7 & 0 & 0 & 0 & 0 & 93.3 & 6.7 & 0 & 0 & 0 & 0 \\
\hline $\begin{array}{lll}\text { Favorit } \quad \times & \text { Dar } \\
\text { Smolyaninovoy } & \\
\end{array}$ & 34 & 82.4 & 11.7 & 5.9 & 0 & 0 & 0 & 58.8 & 32.4 & 8.8 & 0 & 0 & 0 \\
\hline $\begin{array}{l}\text { Favorit } \times \\
\text { Bryanskaya }\end{array}$ & 18 & 66.7 & 22.2 & 11.1 & 0 & 0 & 0 & 61.1 & 38.9 & 0 & 0 & 0 & 0 \\
\hline $\begin{array}{l}18-18-6 / 05 \\
\text { Selechenskaya } 2\end{array}$ & 24 & 50.0 & 29.1 & 12.5 & 4.2 & 4.2 & 0 & 45.8 & 41.7 & 8.3 & 4.2 & 0 & 0 \\
\hline
\end{tabular}




\begin{tabular}{|l|c|c|c|c|c|c|c|c|c|c|c|c|c|c|}
\hline $\begin{array}{l}\text { Selechenskaya 2 } \\
6 / 05\end{array}$ & 57 & 96.5 & 3.5 & 0 & 0 & 0 & 0 & 87.7 & 12.3 & 0 & 0 & 0 & 0 \\
\hline $\begin{array}{l}\text { Litvinovskaya } \times 18-18- \\
6 / 05\end{array}$ & 32 & 90.6 & 9.4 & 0 & 0 & 0 & 0 & 71.9 & 25.0 & 3.1 & 0 & 0 & 0 \\
\hline $\begin{array}{l}\text { Dachnitsa } \\
\text { Agat }\end{array}$ & 22 & 40.9 & 31.8 & 18.2 & 9.1 & 0 & 0 & 45.5 & 31.8 & 13.6 & 9.1 & 0 & 0 \\
\hline $\begin{array}{l}1-5-1 \times \text { Kipiana } \\
\text { 7-79-4 Dar } \\
\text { Smolyaninovoy }\end{array}$ & 67 & 97.0 & 3.0 & 0 & 0 & 0 & 0 & 97.0 & 3.0 & 0 & 0 & 0 & 0 \\
\hline
\end{tabular}

Despite the fact that $57 \%$ of the studied families showed a decrease in the level of resistance of seedlings by the fourth year after planting; nevertheless the share of stable hybrids was $>70 \%$ in the combinations of crosses 1-5-1 $\times$ Kipiana, Litvinovskaya $\times 18-18$ 6/05, Selechenskaya $2 \times 18-18-6 / 05$, Tamerlan $\times$ Favorit, Bryanskiy Agat $\times$ Gulliver. Thus, it becomes obvious that there is a real possibility of creating genotypes tolerant to Sphaerotheca, using stable forms in crosses. The sources of resistance to Sphaerotheca created in the FSBSI FRC for Horticulture are an important link in crop breeding.

Currant gall mite (eriophyid mite) (Cesidophyopsis ribis Westw.) is one of the most harmful crop phytophages, it not only reduces productivity, but also is a carrier of reversion (Reversion pathogen), with lesion of which the ovary is not formed. In recent years, the gall mite has spread significantly in currant plantings, especially with the mass use of mechanization tools [23, 24, 25]. One bud can contain up to 30,000 individuals, and one plant can have more than 100 damaged buds [7, 26]. The pest is widespread in New Zealand, on the European continent, and in Asia, but there is no information about its widespread distribution in North America and Canada [7, 27].

The greatest distribution of gall mite in the conditions of the Bryansk region was noted in the spring of $2009,2011,2017$ and 2020 . It was found that $30 \%$ of the varieties studied in the period from 2005 to 2020 were without signs of phytophagous damage. The varieties that are resistant to the gall mite (plant damage 0 points) include Binar, Ocharovaniye, Shans, Tiben, Vera, Sofiyivskaya, Nimfa, Glariosa, Ben Hope, Gratsiya, Iskusheniye, Ben Sarek, Kipiana, Monisto, Black Magic, Litvinovskaya, Pygmey, Shalunya, Ben Alder, Malenkiy Prints, Sanyuta, Rtishchevskaya, Semiramida, Big Ben, Izyumnaya, Sensei, Nezhdanchik, Dobrynya, Sladkoplodnaya, Ladushka, Gamma, Dar Smolyaninovoy, Sevchanka, Mif, Chelyabinskaya, Ozherelye, Chudnoye Mgnovenie, Chereshneva.

Most varieties in the general collection are susceptible to the pest. In years when the weather conditions are favorable for the spread of the bud mite, $44.3 \%$ of the varieties in the collection plantings have symptoms of mite damage up to 1 point, which already leads to a decrease in plant productivity. And only about $5 \%$ of the varieties in the years of the maximum spread of the pest were damaged by 4-5 points. These are such as Minusinskaya Sladkaya, Blakeston, Lubava, Voevoda, Snezhnaya Koroleva, Yadrenaya, Yubileynaya Kopanya. 


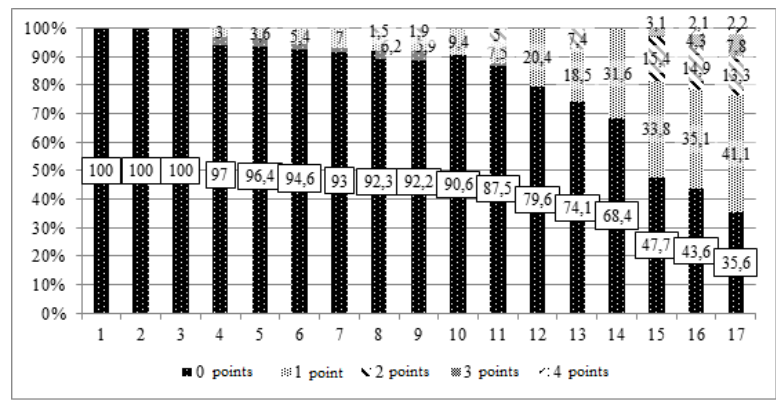

Fig. 1. Segragation of six-year-old hybrid blackcurrant progeny by gall mite infestation (2020) Note: 1 -33-27-1 $\times$ Kipiana; 2 - Favorit $\times$ Dar Smolyaninovoy; 3 - Dar Smolyaninovoy $\times$ 33-27-5; 4 - 1-5-1 $\times$ Kipiana; 5 - 8-4-5 $\times$ Ladushka; 6 - Kipiana $\times 33-27-1 ; 7-33-27-1 \times$ Bryanskiy Agat; 8 Monisto $\times$ Iskusheniye; 9 - 7-79-4 $\times$ Dar Smolyaninovoy; $10-$ Litvinovskaya $\times 18-18-6 / 05 ; 11-$ Chereshneva $\times$ Favorit; 12 - Kipiana $\times 82-3-12 ; 13$ - Bryanskiy Agat $\times$ Litvinovskaya; $14-$ Chudnoye Mgnoveniye $\times$ Mif; $15-$ Dobrynya $\times$ Izyumnaya; $16-$ Kipiana $\times$ 37-34-2; $17-$ Kipiana $\times$ Debryansk

Genotypes that are immune to phytophage are currently involved in the breeding for resistance to gall mite at the Kokinsky CS. High resistance, at the level of immunity, is shown by such varieties as Chudnoye Mgnoveniye, Monisto (derivatives of few-flowered currant), Kipiana, Gamma (derivatives of nutmeg currant) created in the FSBSI VNIISPK, as well as varieties of breeding of the VNII for lupine - Dar Smolyaninovoy, Izyumnaya (derivatives of the Siberian and European black currant subspecies). As a result of the conducted series of crosses, a hybrid fund was created, in which there are no strongly infected seedlings (5 points damage) (Fig. 1). Single hybrids in the families Kipiana $\times 37$ $34-2(2.1 \%)$ and Kipiana $\times$ Debryansk $(2.2 \%)$ were marked with 4 points damage, which is associated with the susceptibility to the pest of the paternal forms. In the progeny of most combinations of crosses, more than $90 \%$ of resistant seedlings were isolated, which indicates the high genetic potential of the parental forms and the prospects for their use in breeding for resistance to gall mite. Families whose progeny did not have a single susceptible seedling, such as Favorit $\times$ Dar Smolyaninovoy, 33-27-1 $\times$ Kipiana and Dar Smolyaninovoy $\times 33-27-1$ are of particular interest.

The result of the breeding search was the creation of forms that combine winter hardiness, resistance to gall mite and Sphaerotheca, with other economically valuable traits. Thus, the elite 33-27-1 combines in its genotype winter hardiness, resistance to Sphaerotheca, mite, large-fruit and friendly maturation. Large-fruited selections 4-63-4 and 72-03-7, along with winter hardiness and resistance to phytopathogens, meet the requirements of suitability for machine harvesting. Selected forms 62-03-7, 63-35-1, 3-13401, 5-82-02, 1-91-01, along with a high level of adaptation, are characterized by dry separation of fruits, their harmonious ripening, straight-growing habitus of the shrub and high productivity.

\section{Conclusions}

1. The conditions of the winter period of the Bryansk region are favorable for most cultivated varieties of black currant, and prolonged winter thaws are the main stress factors of the crop.

2. The best combinations of crosses, initial forms for inbreeding and free pollination were established, in which progeny the greatest number of winter-hardy seedlings resistant to bud mite and Sphaerotheca were isolated. 
3. Selected forms 4-63-4, 72-03-7, 3-37-26/02, 62-03-7, 1-5-1, 63-35-1, 3-134-01, 2803-1, 5-82-02, 1-91-01 and others, which, with high Sphaerotheca-resistance, immunity to bud mite and winter hardiness, also combine other economically useful traits (large-fruit, harmonious ripening, dry separation, etc.).

\section{References}

1. J. Orsavová, I. Hlaváčová, J. Mlček, L. Snopek, L. Mišurcová, Food Chemistry, 284, 323 (2019)

2. G.A. Pantelidis, M. Vasilakakis, G.A. Manganaris, G.R. Diamantidis, Food Chem, 102, 777 (2007)

3. D.E. Pozczola, Food Technol, 55(6), 56 (2001)

4. M.Yu. Akimov, V.V. Bessonov, V.M. Kodentsova, K.I. Eller, O.A. Vrzhesinskaya, N.A. Beketova, O.V. Kosheleva, M.N. Bogachuk, A.D. Malinkin, M.A. Makarenko, et al, Nutrition issues, 89(4), 220 (2020)

5. M.V. Kanshina, Black currant: breeding, genetics, varieties, 160 (2013)

6. G. Zdunić, K. Šavikin, D. Pljevljakusic and B. Djordjevic, Nutritional Composition of Fruit Cultivars, 101 (2015)

7. K.E. Hummer, D.L. Barney, HortTechnology, 12(3), 377 (2002)

8. FAOSTAT, http://www.fao.org

9. The Sate Register of Breeding Achievements Admitted to be Used. V. 1. Plant Cultivars, 421 (2020)

10. T.P. Ogoltsova, Breeding of black currant - past, present, future, 384 (1992)

11. F.F. Sazonov, Breeding of Black Currant in the South-Western Part of the Non-Black Soil Zone of Russia, 304 (2018)

12. M.A. Podgaetsky, Collection of scientific articles: scientific readings, 109 (2011)

13. T.P. Ogoltsova, E.P. Kuminov, Program and Methods of Breeding of Fruit, Berry and Nut-Bearing Crops, 314 (1995)

14. S.D. Knyazev, L.V. Bajnova, Program and Methods of Cultivar Study of Fruit, Berry and Nut-Bearing Crops, 351 (1999)

15. P. Palonen, J. Kemppinen, S. Karhu, Acta Hortic, 1277, 359 (2020)

16. F.F. Sazonov, S.N. Evdokimenko, V.N. Sorokopudov, N.V., Andronova, D.N. Skovorodnikov, Acta Hortic, 1277, 155 (2020)

17. T.L. Woznicki, O.M. Heide, A. Sønsteby, A.-B. Wold, S.F. Remberg, Acta Hortic, 1133, 183 (2016)

18. G.E. Rassell, Breeding for pest and disease resistance, 421 (1982)

19. T.V. Zhidekhina, I.V. Gurieva, Breeding and variety breeding of garden crops, 7(1-2), 73 (2020)

20. S.D. Knyazev, N.S. Levgerova, M.A. Makarkina, A.V. Pikunova, E.S. Salina, E.I. Chekalin, T.V. Yanchuk, M.A. Shavyrkina, Black Currant Breeding: methods, achievements, directions, 328 (2016)

21. A.S. Ravkin, Black currant, 216 (1987)

22. F.F. Sazonov, V.P. Lushcheko, Collection of scientific works of the State Nikitsky Botanical Garden, 148, 217 (2019) 
23. D. Gajek, E. Niemczyk, M. Sekrecka, Integrated Production of Soft Fruits IOBC, 23 (11), 47 (2000)

24. A. Stalažs, Acta Hortic, 946, 333

25. E.G. Akulenko, E.Ya. Yukhacheva, Fruit and berry growing in Russia, 31(1), 12 (2012)

26. O.Z. Metlitsky, A.S. Zeynalov, S.E. Golovin, Methodological guidelines for the protection of mother plants and blackcurrant nurseries from pests and diseases, 8 (2001)

27. A. Stalažs, Acta Hortic, 946, 333 (2012) 